\title{
Temporal Trends in HAM/TSP incidence in Martinique over 25 years (1986-2010): dramatic decrease since 2000
}

\author{
Stephane Olindo ${ }^{1 *}$, Severine Jeannin ${ }^{1}$, Martine Saint-Vil ${ }^{1}$, Aissatou Signate ${ }^{1}$, Mireille Edimonana-Kaptue ${ }^{1}$, \\ Julien Joux', Philippe Cabre ${ }^{1}$, Raymond Cesaire ${ }^{2}$, Agnes Lezin², Didier Smadja' \\ From 17th International Conference on Human Retroviruses: HTLV and Related Viruses \\ Trois Ilets, Martinique. 18-21 June 2015
}

\section{Background}

Human T-Lymphotropic virus 1 (HTLV-1) has been discovered in 1980 and linked to tropical spastic paraparesis (HAM/TSP) in 1985 in Martinique. There is no data on HAM/TSP incidence trends. We report, in the present work, the temporal trends incidence of HAM/TSP in Martinique based on patients diagnosed in our unique Neurology Department in HAM/TSP diagnosis and management over 25 years. Methods: A registry has been set up since 1986 and HAM/TSP characteristics were collected carefully. All patients, living in Martinique, with a definite HAM/TSP onset between 1986 and 2010 were included in the present hospital-based study. The 25-year study time was stratified in five-year and ten-year periods. Crude incidence rates with 95\% confidence interval (95\% CI) were calculated using Poisson distribution for each period. The denominator was based on data provided by French National Institute for Statistical and Economic Studies (http://www.insee.fr) Results: Overall, 153 patients were identified (mean age at onset, $53+/$ 13.1 years; female: male ratio, 4:1). HAM/TSP incidence rates per 100,000 per 5 years $(95 \% \mathrm{CI})$ in $1986-1990$, 1991-1995, 1996-2000, 2001-2005 and 2006-2010 periods were 10 (6.8-7.3), 12.6 (9-16.1), 11.5 (8.1-14.9), 4.4 (2.56.4) and 2 (1.4-3.5). Between the two decades (1991-2000 and 2001-2010), ten-year HAM/TSP incidence rate decreased by $75 \%$ [19.1 (14.8-23.6) versus 4.9 (2.7-7.1)]. Age at onset did not differ between the different periods. Conclusion: There has been a significant decrease (75\%) in HAM/TSP incidence in Martinique in the last decade.

\footnotetext{
* Correspondence: Stephane.olindo.ext@chu-bordeaux.fr

${ }^{1}$ Service de Neurologie, Centre Hospitalier Universitaire de Martinique,

CS 90632 -97 261 Fort-de-France Cedex, Martinique

Full list of author information is available at the end of the article
}

Prevention policies might have been effective in reducing HTLV-1 seroprevalence in our population. However, environmental factors such as parasite burden decrease could also account for HAM/TSP incidence dramatic fall.

\section{Authors' details \\ ${ }^{1}$ Service de Neurologie, Centre Hospitalier Universitaire de Martinique, CS 90632 -97 261 Fort-de-France Cedex, Martinique. ${ }^{2}$ Service de Viro-Immunologie, Centre Hospitalier Universitaire de Martinique, CS 90632 -97 261 Fort-de-France Cedex, Martinique.}

Published: 28 August 2015

doi:10.1186/1742-4690-12-S1-O6

Cite this article as: Olindo et al: Temporal Trends in HAM/TSP incidence in Martinique over 25 years (1986-2010): dramatic decrease since 2000. Retrovirology 2015 12(Suppl 1):O6.
Submit your next manuscript to BioMed Central and take full advantage of:

- Convenient online submission

- Thorough peer review

- No space constraints or color figure charges

- Immediate publication on acceptance

- Inclusion in PubMed, CAS, Scopus and Google Scholar

- Research which is freely available for redistribution

Submit your manuscript at www.biomedcentral.com/submit
() Biomed Central 